Research Article

\title{
Experimental Investigation on Hydroabrasive Erosion of Steel Fiber UHPC and Rubber UHPC
}

\author{
Shuangxi Li, ${ }^{1,2}$ Liang Tang $\mathbb{D}^{1,2}$ Wenyou Shi, ${ }^{1,2}$ and Congchun Zhong ${ }^{1,2}$ \\ ${ }^{1}$ College of Hydraulic and Civil Engineering, Xinjiang Agricultural University, Urumqi, Xinjiang 830052, China \\ ${ }^{2}$ Xinjiang Key Laboratory of Hydraulic Engineering Security and Water Disasters Prevention, Urumqi, Xinjiang 830052, China
}

Correspondence should be addressed to Liang Tang; liangtangeducation@163.com

Received 16 July 2020; Accepted 30 November 2020; Published 8 December 2020

Academic Editor: Michelina Catauro

Copyright (c) 2020 Shuangxi Li et al. This is an open access article distributed under the Creative Commons Attribution License, which permits unrestricted use, distribution, and reproduction in any medium, provided the original work is properly cited.

Steel fiber ultrahigh performance concrete (UHPC) and rubber ultrahigh performance concrete (UHPC) adopt the methods of "rigidity overcomes rigidity" and "softness overcomes rigidity," respectively, to resist the abrasion and cavitation erosion caused by water flow carrying large solid particles. The above two have been applied in engineering successfully, but there are differences in material properties, mechanical properties, and microstructures. In this study, we will analyze the difference of abrasion resistance performance of the above two kinds of UHPC, in terms of, for example, compressive strength, abrasion resistance strength, abrasion rate, and microstructure in different ages, so as to provide a new material and method. The results indicate that the steel fiber UHPC compressive strength is higher than that of rubber UHPC (containing 1\% steel fiber), and the abrasion resistance performance of steel fiber UHPC is lower than that of rubber UHPC (containing 1\% steel fiber) when the rubber content is $10 \%$ and $12.5 \%$. With the increase of steel fiber content, the compressive strength of steel fiber UHPC is not significantly improved, and the influence of water-binder ratio (W/B) on UHPC is higher than that of steel fiber content. With the increase of rubber content, the rubber UHPC compressive strength decreases, abrasion resistance strength decreases, and abrasion rate increases. The cement paste-aggregate interface transition zone (ITZ) of steel fiber UHPC and rubber UHPC has few internal voids and high compactness; however, the ITZ of steel fiber UHPC is denser than that of rubber UHPC.

\section{Introduction}

As we all know, the common abrasion occurs in hydraulic structures (such as spillway, overflow dam, and spillway tunnel), pavement (such as cement concrete pavement and airport runway), workshop floor, and pier to which friction forces are applied due to relative motion between the surfaces and moving objects [1-3]. Specifically, the abrasion of hydraulic concrete is mainly caused by the following: (1) The small particles of suspended matter move at high speed along with the flow. When passing through the flow surface of hydraulic structures, the surface is cut, worn, and collided. With the increase of abrasion and peel failure, the overflow surface will have uneven abrasion pits, which will further intensify the impact and abrasion failure of the suspended particles on the hydraulic concrete. (2) The bed load with large particles will pass through the overflow surface by sliding, jumping, and rolling under the action of high-speed water flow, which will result in sliding friction and impact collision of the contact surface. In the impact areas, a large local stress effect will occur; when the stress effect exceeds the design strength of concrete, local failure will occur [4-6]. Based on the above analysis, it is generally believed that the bed load with large particles is more serious damage than that of the suspended load. Therefore, for the arid desert ecological environment in Xinjiang, China, a unique precipitation and runoff law has been formed. Inland river is the main river, the river in mountainous area has a large slope, and the flow contains large particles of bed load. The heavy silt and rolling stones brought by the flood season in Xinjiang also caused the more serious abrasion and cavitation erosion of the hydraulic structures [6-8].

Therefore, it is necessary to improve the abrasion resistance performance of concrete to reduce the damage of 
poor abrasion resistance caused by raw materials. Most scholars believe that the strength of concrete is positively related to abrasion resistance [9]. Siddique and Khatib studied the abrasion resistance of fly ash concrete and pointed out that the abrasion resistance of concrete had a strong correlation with the mechanical properties, and the increase of strength and elastic modulus would improve the abrasion resistance [10]. Li et al. studied the abrasion resistance of concrete by doping with nanoparticles, which showed that the abrasion resistance of concrete increased with the increase of compressive strength [11]. Furthermore, it is an effective way to improve the strength of abrasion resistant materials, which can be generally achieved by (1) coating and assembling the outer protective materials; (2) inorganic concrete (fiber reinforced concrete, silica fume concrete, fly ash concrete, ultrahigh abrasion resistance concrete, etc.) [12-16]; (3) organic concrete (resin mortar concrete, rubber concrete, modified concrete, etc.) [17, 18]. Among them, steel fiber reinforced concrete (SFRC) and rubber concrete are the most representative.

It is of great significance to study the SFRC. Steel fiber can form a uniform random support system in the concrete, which provides a hoop effect for the concrete and restricts the development of transverse deformation and micro cracks of the concrete. Horszczaruk et al. showed that when the ratio of length to diameter of steel fiber was more than 50, the abrasion resistant performance of SFRC was better, and the abrasion degree of SFRC surface depends on the distribution of steel fibers on the concrete and the angle of impact abrasion [19]. Cheng et al. found that the compressive strength of concrete increased significantly when only steel fiber was added, but the influence of abrasion resistance was not significant. When silicon powder was added, with the increase of steel fiber and the decrease of water-binder ratio, the compressive strength and abrasion resistance performance were improved; when composite materials were doped with SFRC, the abrasion resistance of cement-based composite increased [20]. Momber studied the abrasion resistant performance of SFRC and found that steel fiber could significantly improve the cavitation resistance of concrete, while steel fiber did not always improve the abrasion resistance of concrete. When the flow rate was lower than $10 \mathrm{~m} / \mathrm{s}$, the abrasion resistant performance of concrete was lower than that of ordinary concrete [21]. More than one study showed that the SFRC improves the compressive strength and abrasion resistance performance but often occurs in the mixing fiber in concrete uniform distribution and twisting clusters extremely easily. In turn, it reduces the workability of concrete and causes the poor uniformity of concrete.

Rubber concrete is composed of rubber particles or rubber powder, which is mixed into concrete according to certain principles. Compared with ordinary concrete, rubber concrete has the advantages of high abrasion resistance strength and high toughness; it has been applied in hydraulic structures, pavement, and bridge covers [22]. Ozbay et al. tested the compressive strength, abrasion resistance, and energy absorption capacity of concrete with different mixtures. The results showed that the addition of rubber particles reduced the compressive strength of concrete and higher rubber aggregate content would reduce the mass loss and abrasion depth, improving the energy absorption capacity of concrete [23]. Thomas et al. studied the abrasion resistance of rubber concrete and found that rubber had a linear positive effect on the abrasion resistance performance [24]. Li et al. used crumb rubber in waste tire to replace part of fine aggregate and studied abrasion resistance and impact resistance performance. The results showed that the compressive strength of rubber concrete was slightly lower than that of traditional concrete, but the abrasion resistance of crumb rubber concrete (CRC) was the opposite [25]. Rubber particles filled the void of concrete to make the self-compacting degree of concrete higher; they also improved the abrasion resistance performance and impact resistance of concrete. However, rubber is an elastic material which reduces the compressive and tensile strength of concrete, so improving the compressive strength and maintaining its abrasion resistance performance are the focus of investigation [26].

The above investigation into the resisting erosion and abrasion of SFRC and rubber concrete adopts the following methods, respectively: (1) "rigidity overcomes rigidity" for adopting high-strength concrete, aiming at erosion and abrasion damage of bed load with large particles in high water head reservoir area; (2) "softness overcomes rigidity" for adopting flexible materials to resist erosion and abrasion damage, which is applicable to hydraulic structures with low water head. From the above analysis, we can see that the two kinds of concrete have their own advantages. The abrasion resistance performance of rubber concrete is higher than that of SFRC, but the compressive strength is the opposite. The compressive strength of SFRC is higher, but the abrasion resistance performance is lower than that of rubber concrete. Based on this, this paper will combine the advantages of SFRC and rubber concrete, adopting low water-binder ratio and adding silicon powder, slag, and other admixtures, respectively, to prepare steel fiber UHPC and rubber UHPC (containing 1\% steel fiber) and analyze their compressive strength, abrasion resistance strength, abrasion rate, and microstructure in different ages. Meanwhile, the reason is analyzed for the difference between two kinds of UHPC in abrasion resistance performance which provides a new material and method to solve the abrasion resistance failure of hydraulic concrete [27-29].

\section{Materials and Methods}

\subsection{Materials. The following materials are used.}

Cement: density is $3.2 \mathrm{~g} \cdot \mathrm{cm}^{-3}$; specific surface area is $27.4 \mathrm{~m}^{2} \cdot \mathrm{kg}^{-1}$; flexural strength and compressive strength are 8.6 $\mathrm{MPa}$ and $61.1 \mathrm{MPa}$ in $28 \mathrm{~d}$, respectively.

Fly ash: density is $2.31 \mathrm{~g} \cdot \mathrm{cm}^{-3}$; specific surface area is $44427.4 \mathrm{~m}^{2} \cdot \mathrm{kg}^{-1}$; fineness is $28.6 \%$.

Slag powder: density is $2.9 \mathrm{~g} \cdot \mathrm{cm}^{-3}$; specific surface area is $460 \mathrm{~m}^{2} \cdot \mathrm{kg}^{-1}$; fineness is $13.42 \%$; the chemical composition is shown in Table 1. 
TABle 1: Chemical composition of slag powder and silica powder.

\begin{tabular}{lccccccccccc}
\hline Name & $\mathrm{SiO}_{2}$ & $\mathrm{Fe}_{2} \mathrm{O}_{3}$ & $\mathrm{Al}_{2} \mathrm{O}_{3}$ & $\mathrm{R}_{2} \mathrm{O}$ & $\mathrm{CaO}$ & $\mathrm{Na}_{2} \mathrm{O}$ & $\mathrm{K}_{2} \mathrm{O}$ & $\mathrm{MgO}$ & $\mathrm{SO}_{3}$ & $\mathrm{C} 5 \mathrm{l}-$ \\
\hline Silica powder & 91.77 & 0.92 & 0.56 & 1.14 & 0.58 & 0.46 & 0.17 & 1.47 & 0.97 & 0.200 \\
Slag powder & 35.11 & 0.72 & 10.14 & 0.24 & 42.58 & 0.35 & 0.76 & 7.57 & - & - \\
\hline
\end{tabular}

Silica powder: density is $2.27 \mathrm{~g} \cdot \mathrm{cm}^{-3}$; specific surface area is $20000 \mathrm{~m}^{2} \cdot \mathrm{kg}^{-1}$; the chemical composition is shown in Table 1.

Aggregate: natural sand (NS), quartz sand (QS), and synthetic sand (SS) are shown in Table 2.

Water reducing agent: polycarboxylic high performance water reducing agent is used, and the water reducing rate is more than $30 \%$.

Rubber: density is $1119 \mathrm{~kg} / \mathrm{m}^{3} ; 8$ mesh $(2-4 \mathrm{~mm}), 16$ mesh (1-2 mm), 40 mesh $(0.2-0.4 \mathrm{~mm})$, as shown in Figures 1(a), 1(b), and 1(c).

Steel fiber: the wave type steel fiber is shown in Figure $1(\mathrm{~d})$ and the parameters are shown in Table 3.

2.2. Experimental Schemes. The first scheme is the orthogonal experiment of three factors and three levels of steel fiber UHPC, as shown in Table $4.17 \%$ slag powder, $10 \%$ quartz powder, and $8 \%$ silica powder are added to replace part of the cement. In addition, (1) the water-binder ratio (W/B) is taken as a factor, and the three factors are proposed to account for $0.18 \%, 0.2 \%$, and $0.22 \%$, respectively; (2) the amount of steel fiber is taken as a factor, and the three factors are proposed to account for $0.5 \%, 1 \%$, and $1.5 \%$, respectively; (3) natural sand (NS), synthetic sand (SS), and quartz sand (QS) aggregate are considered as a factor.

The second scheme is rubber UHPC three-factor threelevel orthogonal experiments, as shown in Table 5. The water-binder ratio $(\mathrm{W} / \mathrm{B})$ is 0.2 , and $1 \%$ steel fiber, $5 \%$ fly ash, and $15 \%$ silica powder are added to replace part of cement. (1) Taking the rubber content as a factor, the proportion of the three factors is $10 \%, 12.5 \%$, and $15 \%$, respectively; (2) taking the particle size of rubber as a factor, the proportion of rubber particle size is 40 mesh, 16 mesh, and 8 mesh, respectively; (3) 45\%,44\%, and 43\% quartz sand are considered as a factor.

2.3. Experimental Methods. According to the standard of reactive powder concrete (GB/T 31387-2015) and the test code for hydraulic concrete (DL/T 5150-2001) [30, 31], the cube compression test was carried out with age of $3 \mathrm{~d}, 7 \mathrm{~d}$, and $28 \mathrm{~d}$. The size of compression test piece was a cube of $100 \mathrm{~mm} \times 100 \mathrm{~mm} \times 100 \mathrm{~mm}$.

To evaluate the abrasion resistance performance of UHPC according to ASTM C1138 underwater method and the test code for hydraulic concrete (SL352-2006) underwater steel ball method [32, 33], a $\varphi 300 \mathrm{~mm} \times 100 \mathrm{~mm}$ cylindrical concrete specimen was prepared before the abrasion resistance test, and the abrasion resistance specimens were placed in water for more than $48 \mathrm{~h}$. The test apparatus of underwater steel ball method is presented in Figure 2. The motor speed of the abrasion resistance test machine is set to $1200 \mathrm{r} / \mathrm{min}$, and the impact abrasion time is set to $72 \mathrm{~h}$. As the abrasion of the UHPC specimen is not very obvious during the $72 \mathrm{~h}$ period, the abrasion time of the specimen is extended to $168 \mathrm{~h}$ without changing any other instruments. After the test piece is fully saturated with water absorption, surface moisture is wiped off, and the mass is recorded as $M_{1}$. After weighing, the concrete specimen is loaded into the test instrument for abrasion resistance test. After the test, the specimen is taken out and cleaned and the surface moisture is wiped, which records the mass as $M_{2}$. The abrasion resistance strength and abrasion rate are taken as the indexes to evaluate the abrasion resistance performance of concrete. The abrasion resistance strength is calculated as follows:

$$
R_{n}=\frac{\mathrm{TA}}{M_{1}-M_{2}}
$$

where $R_{\mathrm{n}}$ is abrasion resistance strength of concrete specimen, time required for abrasion mass per unit area, $h /(\mathrm{kg} /$ $\left.\mathrm{m}^{2}\right)$; $T$ is cumulative time of abrasion resistance test, $h$; A is area of concrete specimen under abrasion, $m^{2}$; and $M_{1}, M_{2}$ are mass of test piece before and after, respectively, kg.

The abrasion rate of concrete specimen is calculated as follows:

$$
L=\frac{\Delta M}{M_{2}} \times 100 \%,
$$

where $L$ is abrasion rate of concrete specimen, $\%$, and $\Delta \mathrm{M}$ is mass difference of specimen loss before and after the test, $\mathrm{kg}$.

\section{Experimental Results and Analysis}

The UHPC was prepared according to the orthogonal test scheme designed above, and the test pieces have the sizes of $100 \mathrm{~mm} \times 100 \mathrm{~mm} \times 100 \mathrm{~mm}$ for compression specimen and $\varphi 300 \mathrm{~mm} \times 100 \mathrm{~mm}$ for abrasion resistance specimen. The curing was carried out in the standard curing room, and the compressive strength of the specimens with ages of $3 \mathrm{~d}, 7 \mathrm{~d}$, and $28 \mathrm{~d}$ was measured. The abrasion resistance test was conducted on the UHPC specimens cured to $28 \mathrm{~d}$.

3.1. Compressive Test Results and Analysis. The compressive strength test results of different ages of steel fiber UHPC and rubber UHPC are shown in Tables 6 and 7 and Figure 3.

According to Table 6, it is not difficult to find that under certain water-binder ratio $(W / B)$ and aggregate, the UHPC compressive strength increases with the increase of steel fiber content, but it is not obvious. The main reason is that there are few defects in the inner structure of UHPC, and the addition of steel fiber increases the weak layer of interface, which has no obvious effect on the improvement of cube compressive bearing capacity; while there are many internal 
Table 2: Physical index of sand.

\begin{tabular}{|c|c|c|c|c|c|}
\hline $\begin{array}{l}\text { Type of } \\
\text { aggregate }\end{array}$ & $\begin{array}{l}\text { Loose bulk density } \\
\left(\mathrm{kg} / \mathrm{m}^{3}\right)\end{array}$ & $\begin{array}{c}\text { Loose bulk porosity } \\
(\%)\end{array}$ & $\begin{array}{l}\text { Saturated surface dry density } \\
\qquad\left(\mathrm{kg} / \mathrm{m}^{3}\right)\end{array}$ & $\begin{array}{c}\text { Saturated dry water } \\
\text { absorption }(\%)\end{array}$ & $\begin{array}{c}\text { Mud content } \\
(\%)\end{array}$ \\
\hline Natural sand & 1731.84 & 35.2 & 2674.50 & 1.18 & 0.05 \\
\hline Quartz sand & 1733.99 & 38.32 & 2649.91 & 0.89 & 0.04 \\
\hline Synthetic sand & 1834.05 & 37.33 & 2830.14 & 1.56 & 0.07 \\
\hline
\end{tabular}

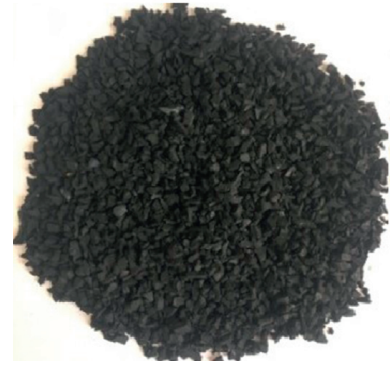

(a)

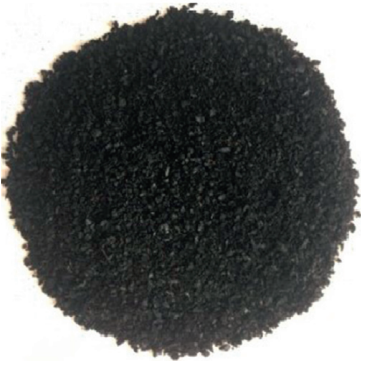

(b)

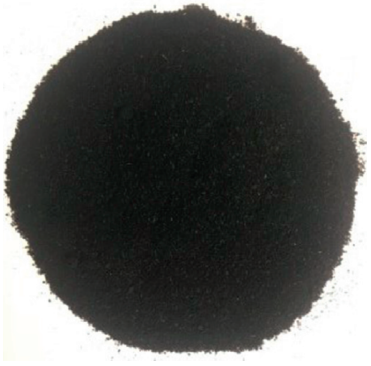

(c)

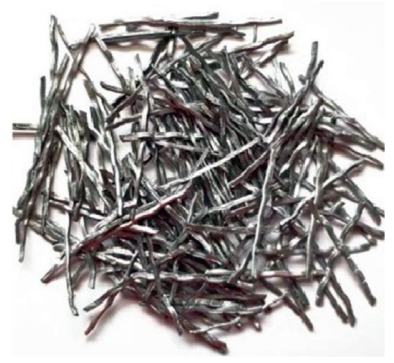

(d)

Figure 1: Rubber particles and steel fibers: (a) 8 mesh (2-4 mm); (b) 16 mesh (1-2 mm); (c) 40 mesh (0.2-0.4 mm); (d) wave type steel fiber.

TABle 3: Parameters of steel fiber.

\begin{tabular}{|c|c|c|c|c|c|c|}
\hline Steel fiber & Tensile strength (MPa) & Length $(\mathrm{mm})$ & Diameter $(\mathrm{mm})$ & Length-diameter ratio & Density $\left(\mathrm{g} / \mathrm{cm}^{3}\right)$ & Number per gram \\
\hline Wave type & 1200 & 30 & 0.5 & 50 & 7.85 & 14 \\
\hline
\end{tabular}

TABLE 4: Steel fiber UHPC mix proportion $\left(\mathrm{kg} / \mathrm{m}^{3}\right)$.

\begin{tabular}{lcccccc}
\hline Group number & $W / B$ & Steel fiber (\%) & Type of aggregate & Slag powder (\%) & Quartz powder (\%) & Water reducing agent \\
\hline$A_{1}$ & 0.18 & 0.5 & NS & 17 & 8 & 7.5 \\
$A_{2}$ & 0.18 & 1.0 & QS & 17 & 8 & 9 \\
$A_{3}$ & 0.18 & 1.5 & SS & 17 & 8 & 8.5 \\
$A_{4}$ & 0.20 & 0.5 & QS & 17 & 8 & 9 \\
$A_{5}$ & 0.20 & 1.0 & SS & 17 & 8 & 11 \\
$A_{6}$ & 0.20 & 1.5 & NS & SS & 17 & 8 \\
$A_{7}$ & 0.22 & 0.5 & NS & 17 & 8 & 10.5 \\
$A_{8}$ & 0.22 & 1.0 & QS & & & 17 \\
$A_{9}$ & 0.22 & 1.5 & &
\end{tabular}

TABle 5: Rubber UHPC mix proportion $\left(\mathrm{kg} / \mathrm{m}^{3}\right)$.

\begin{tabular}{|c|c|c|c|c|c|c|c|c|}
\hline Group number & $\begin{array}{c}\text { Rubber } \\
\text { content (\%) }\end{array}$ & $\begin{array}{c}\text { Rubber } \\
\text { particle size (mesh) }\end{array}$ & Sand (\%) & $W / B$ & $\begin{array}{c}\text { Silica } \\
\text { powder }(\%)\end{array}$ & Fly ash (\%) & Steel fiber (\%) & Water reducing agent \\
\hline$B_{1}$ & 10 & 40 & 45 & 0.2 & 15 & 5 & 1 & 10.0 \\
\hline$B_{2}$ & 10 & 16 & 45 & 0.2 & 15 & 5 & 1 & 11.0 \\
\hline$B_{3}$ & 10 & 8 & 45 & 0.2 & 15 & 5 & 1 & 12.5 \\
\hline$B_{4}$ & 12.5 & 40 & 44 & 0.2 & 15 & 5 & 1 & 11.5 \\
\hline$B_{5}$ & 12.5 & 16 & 44 & 0.2 & 15 & 5 & 1 & 12.0 \\
\hline$B_{6}$ & 12.5 & 8 & 44 & 0.2 & 15 & 5 & 1 & 11.0 \\
\hline$B_{7}$ & 15 & 40 & 43 & 0.2 & 15 & 5 & 1 & 13.0 \\
\hline$B_{8}$ & 15 & 16 & 43 & 0.2 & 15 & 5 & 1 & 12.0 \\
\hline$B_{9}$ & 15 & 8 & 43 & 0.2 & 15 & 5 & 1 & 12.0 \\
\hline
\end{tabular}

defects in ordinary low-strength concrete, the hoop effect is obviously stronger than the defect after the addition of steel fiber, and the compressive strength is obviously improved. It can also be seen from Table 6 that the development rule of compressive strength in $3 \mathrm{~d}, 7 \mathrm{~d}$, and $28 \mathrm{~d}$ is as follows: the curing age plays a crucial role in the growth of concrete strength; the longer the curing age is, the higher the compressive strength will be. Meanwhile, when a certain amount 


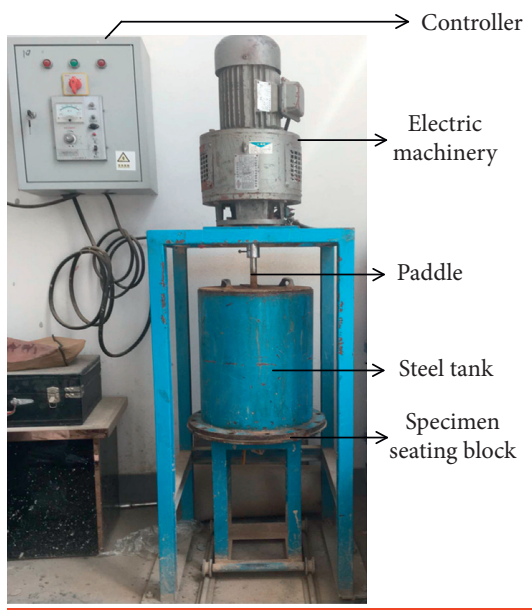

(a)

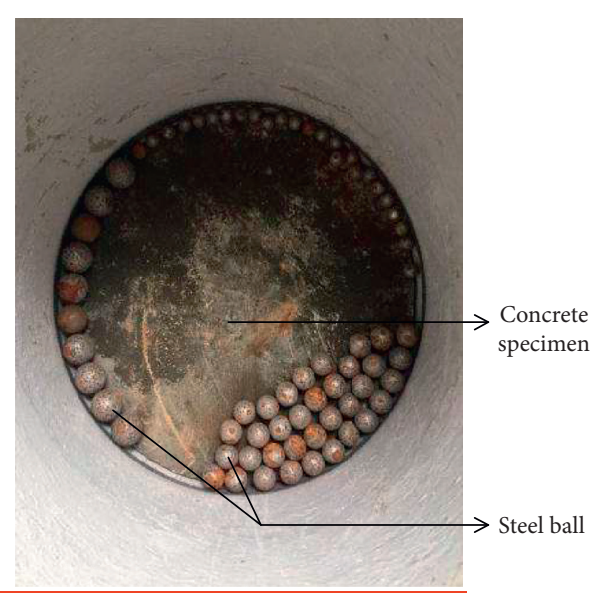

(b)

Figure 2: Test apparatus of underwater steel ball method: (a) test apparatus; (b) steel balls.

TABLE 6: Compressive strength test results of steel fiber UHPC orthogonal test (MPa).

\begin{tabular}{|c|c|c|c|c|c|c|c|c|c|c|}
\hline \multirow[t]{2}{*}{ Group number } & \multirow[t]{2}{*}{$W / B$} & \multirow{2}{*}{$\begin{array}{c}\text { Steel } \\
\text { fiber (\%) }\end{array}$} & \multirow[t]{2}{*}{ Type of aggregate } & \multirow[t]{2}{*}{ Slag powder (\%) } & \multirow{2}{*}{$\begin{array}{c}\text { Quartz } \\
\text { powder (\%) }\end{array}$} & \multirow{2}{*}{$\begin{array}{c}\text { Silica } \\
\text { powder (\%) }\end{array}$} & \multirow{2}{*}{$\begin{array}{c}\text { Water } \\
\text { reducing agent }\end{array}$} & \multicolumn{3}{|c|}{$\begin{array}{c}\text { Compressive } \\
\text { strength }(\mathrm{MPa})\end{array}$} \\
\hline & & & & & & & & $3 \mathrm{~d}$ & $7 \mathrm{~d}$ & $28 \mathrm{~d}$ \\
\hline$A_{1}$ & 0.18 & 0.5 & NS & 17 & 10 & 8 & 7.5 & 90.3 & 111.6 & 129.4 \\
\hline$A_{2}$ & 0.18 & 1.0 & QS & 17 & 10 & 8 & 9 & 90.1 & 110.8 & 137.1 \\
\hline$A_{3}$ & 0.18 & 1.5 & SS & 17 & 10 & 8 & 8.5 & 89.9 & 115.5 & 134.2 \\
\hline$A_{4}$ & 0.20 & 0.5 & QS & 17 & 10 & 8 & 9 & 76.8 & 105.4 & 121.5 \\
\hline$A_{5}$ & 0.20 & 1.0 & SS & 17 & 10 & 8 & 11 & 85.6 & 104.9 & 125.0 \\
\hline$A_{6}$ & 0.20 & 1.5 & NS & 17 & 10 & 8 & 10.5 & 87.6 & 108.8 & 127.6 \\
\hline$A_{7}$ & 0.22 & 0.5 & SS & 17 & 10 & 8 & 10.5 & 70.3 & 97.7 & 120.8 \\
\hline$A_{8}$ & 0.22 & 1.0 & NS & 17 & 10 & 8 & 11.5 & 69.3 & 98.5 & 123.2 \\
\hline$A_{9}$ & 0.22 & 1.5 & QS & 17 & 10 & 8 & 13 & 77.1 & 103.0 & 119.6 \\
\hline
\end{tabular}

TABLE 7: Compressive strength test results of rubber UHPC orthogonal test (MPa).

\begin{tabular}{|c|c|c|c|c|c|c|c|c|c|c|c|}
\hline \multirow[t]{2}{*}{ Group number } & \multirow{2}{*}{$\begin{array}{c}\text { Rubber } \\
\text { content }(\%)\end{array}$} & \multirow{2}{*}{$\begin{array}{c}\text { Rubber } \\
\text { particle size (mesh) }\end{array}$} & \multirow[t]{2}{*}{ Sand (\%) } & \multirow[t]{2}{*}{$W / B$} & \multirow{2}{*}{$\begin{array}{c}\text { Silica } \\
\text { powder (\%) }\end{array}$} & \multirow{2}{*}{$\begin{array}{c}\text { Fly } \\
\text { ash (\%) }\end{array}$} & \multirow{2}{*}{$\begin{array}{c}\text { Steel } \\
\text { fiber (\%) }\end{array}$} & \multirow{2}{*}{$\begin{array}{c}\text { Water } \\
\text { reducing agent }\end{array}$} & \multicolumn{3}{|c|}{$\begin{array}{c}\text { Compressive } \\
\text { strength }(\mathrm{MPa})\end{array}$} \\
\hline & & & & & & & & & $3 \mathrm{~d}$ & $7 \mathrm{~d}$ & $28 \mathrm{~d}$ \\
\hline$B_{1}$ & 10 & 40 & 43 & 0.2 & 15 & 5 & 1 & 10.0 & 55.7 & 78.9 & 106.6 \\
\hline$B_{2}$ & 10 & 16 & 44 & 0.2 & 15 & 5 & 1 & 11.0 & 58.6 & 75.2 & 98.6 \\
\hline$B_{3}$ & 10 & 8 & 45 & 0.2 & 15 & 5 & 1 & 12.5 & 65.4 & 84.3 & 114.1 \\
\hline$B_{4}$ & 12.5 & 40 & 43 & 0.2 & 15 & 5 & 1 & 11.5 & 50.1 & 69.2 & 97.5 \\
\hline$B_{5}$ & 12.5 & 16 & 44 & 0.2 & 15 & 5 & 1 & 12.0 & 51.3 & 71.3 & 84.6 \\
\hline$B_{6}$ & 12.5 & 8 & 45 & 0.2 & 15 & 5 & 1 & 11.0 & 55.9 & 79.5 & 102.7 \\
\hline$B_{7}$ & 15 & 40 & 43 & 0.2 & 15 & 5 & 1 & 13.0 & 45.2 & 67.7 & 85.8 \\
\hline$B_{8}$ & 15 & 16 & 44 & 0.2 & 15 & 5 & 1 & 12.0 & 49.8 & 64.3 & 75.8 \\
\hline$B_{9}$ & 15 & 8 & 45 & 0.2 & 15 & 5 & 1 & 12.0 & 53.6 & 73.5 & 94.4 \\
\hline
\end{tabular}

of steel fiber and aggregate are added, the lower the waterbinder ratio $(W / B)$ is, the higher the compressive strength is; the influence of aggregate type on it is not obvious, and such factors as steel fiber and water-binder ratio $(W / B)$ can be given priority in the preparation of UHPC.

By analyzing Tables 6 and 7 combined with Figure 2, in the case of $1 \%$ steel fiber and 0.2 water-binder ratio $(W / B)$, the compressive strength of rubber UHPC at $3 \mathrm{~d}, 7 \mathrm{~d}$, and 28 $\mathrm{d}$ with different proportions and different rubber particle sizes decreased, indicating that the compressive strength of steel fiber UHPC is better than that of rubber UHPC (containing 1\% steel fiber). With the increase of rubber content, the compressive strength decreases, and the proportion of decrease is different when the same content and different particle size rubbers are added. Among them, the 3 $\mathrm{d}$ compressive strength decreases the most, and the $28 \mathrm{~d}$ compressive strength of rubber UHPC gradually decreases with the increase of rubber content. The content of rubber 


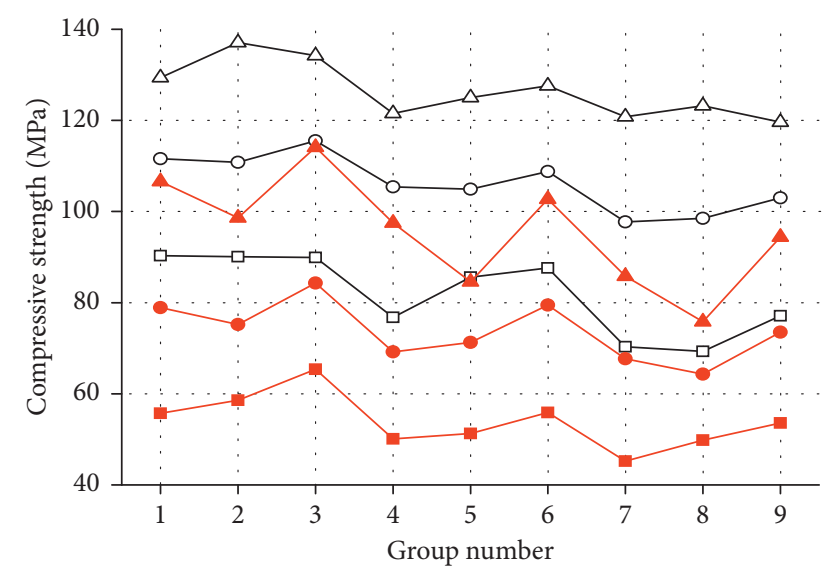

$\square-3 \mathrm{~d}$ steel fiber UHPC $--3 \mathrm{~d}$ rubber UHPC

-○- $7 \mathrm{~d}$ steel fiber UHPC - - $7 \mathrm{~d}$ rubber UHPC

$\triangle 28 \mathrm{~d}$ steel fiber UHPC $\triangle 28 \mathrm{~d}$ rubber UHPC

Figure 3: Compressive strength of steel fiber UHPC and rubber UHPC.

particles has a great influence on the compressive strength of rubber UHPC; when the rubber content of rubber UHPC increases from $10 \%$ to $12.5 \%$, the compressive strength decreases from $24.9 \%$ to $38.1 \%$; when the rubber content of rubber UHPC increased from $12.5 \%$ to $15 \%$, the compressive strength decreased from $30.9 \%$ to $44.5 \%$. This is because (1) the cementation force of rubber as organic material and concrete is weaker than that of sand and concrete; in addition, the compressive strength of rubber itself is not high, and the compressive capacity is not as good as that of steel fiber and fine aggregate, which could cut off the transmission path in the process of stress transmission; (2) when the rubber content increases, the micropores in concrete are filled, but the numbers of concrete mesopores and macropores are also increased, which is one of the main reasons for the low compressive strength of rubber UHPC. It can also be seen from Table 7 that rubber particle size has a significant influence on rubber UHPC compressive strength, of which 16 mesh rubber is the largest, 40 mesh rubber is the second, and 8 mesh rubber is the smallest; according to the influence degree of rubber on rubber UHPC compressive strength of concrete, rubber content $>$ rubber particle size.

3.2. Abrasion Resistance Test Results and Analysis. The abrasion resistance strength test results of steel fiber UHPC and rubber UHPC after $168 \mathrm{~h}$ impact abrasion are shown in Tables 8 and 9 and Figures 4 and 5 .

It can be seen from Table 8 that after $168 \mathrm{~h}$ abrasion resistance test, with the increase of steel fiber content proportion, the abrasion resistance strength generally shows a downward trend, and the abrasion rate generally shows an increasing trend under the condition of a certain water-binder ratio $(W / B)$. This is because the steel fiber belongs to inorganic material; with the increase of the content of steel fiber, the average of steel fiber in the matrix increases gradually, which will cause the phenomenon of crossing, winding, and overlapping between the fibers, and then reduces the bond between the aggregate, flocculent paste, and fiber, which will further reduce the abrasion resistance strength and increase the abrasion rate. Meanwhile, with the increase of waterbinder ratio $(W / B)$, the abrasion resistance strength decreases and the abrasion rate increases under the condition of certain steel fiber content and the same kind of aggregate. The reason is that the strength of UHPC steel fiber decreases due to high water-binder ratio $(W / B)$. After the strength is reduced, the surface is easy to destroy by impact abrasion and the steel fiber will be exposed. After long-term washing and grinding, the steel fiber falls off from the concrete surface, resulting in a greater mass loss in the steel fiber UHPC. Through the comparison of variance, range analysis, and compressive strength of steel fiber UHPC, we found that the influence of aggregate type on the offset abrasion strength is small.

It can be seen from Tables 8 and 9 and the data in Figure 3 that when $1 \%$ steel fiber and 0.2 water-binder ratio $(W / B)$ are added quantitatively, and $10 \%$ and $12.5 \%$ rubber particles are added, the abrasion resistance strength of rubber UHPC is significantly higher than that of steel fiber UHPC. After adding 15\% rubber particles, the abrasion resistance strength of rubber UHPC is generally lower than that of steel fiber UHPC; however, with the increase of rubber particle size, the abrasion resistance strength of rubber UHPC is higher than that of steel fiber UHPC. This is because the toughness of rubber particles is larger than that of steel fiber, sand, and stone, and the impact abrasion energy has a strong absorption effect, which postpones the destruction of concrete to a certain extent. With the development of the degree of abrasion, after the cement stone around the rubber particles is washed off and the rubber particles fall off, the new rubber particles will be exposed to protect the cement stone again. In this reciprocating way, the abrasion resistance performance of rubber UHPC is significantly improved.

According to Table 9 and Figure 3, the abrasion resistance performance of rubber UHPC is improved after $1 \%$ steel fiber is added quantitatively. When the rubber particle size is the same, the content of rubber increases from $10 \%$ to $15 \%$, and the abrasion resistance performance of rubber UHPC significantly decreases. When the rubber content is the same and the rubber particle size increases from 40 mesh (the length is $0.2-0.4 \mathrm{~mm}$ ) to 8 mesh (the length is $2-4 \mathrm{~mm}$ ), the abrasion resistance strength increases and the abrasion rate decreases. This is because (1) the higher the proportion of rubber in UHPC is, the stronger the absorption of abrasion energy is; however, at the same time, the lower the strength of rubber UHPC, the smaller the cementation and consolidation effect of cement stone and rubber particles, and the rubber particles will be easily washed and ground off, which will reduce the protective effect on cement stone; (2) when the rubber particle size is small, the rubber particles are easy to wash away so that they lose their protection effect on cement stone, reducing the abrasion resistance performance. 
TABLE 8: Test results of $168 \mathrm{~h}$ abrasion resistance strength of steel fiber UHPC $\mathrm{h} /\left(\mathrm{kg} / \mathrm{m}^{2}\right)$.

\begin{tabular}{|c|c|c|c|c|c|c|c|c|c|}
\hline $\begin{array}{l}\text { Group } \\
\text { number }\end{array}$ & $\begin{array}{c}W / \\
B\end{array}$ & $\begin{array}{c}\text { Steel } \\
\text { fiber } \\
(\%)\end{array}$ & $\begin{array}{c}\text { Type of } \\
\text { aggregate }\end{array}$ & $\begin{array}{c}\text { Slag } \\
\text { powder } \\
(\%)\end{array}$ & $\begin{array}{c}\text { Quartz } \\
\text { powder (\%) }\end{array}$ & $\begin{array}{c}\text { Silica } \\
\text { powder (\%) }\end{array}$ & $\begin{array}{c}\text { Water reducing } \\
\text { agent }\end{array}$ & $\begin{array}{c}28 \mathrm{~d} \text { abrasion } \\
\text { resistance strength } \\
\mathrm{h} /\left(\mathrm{kg} / \mathrm{m}^{2}\right)\end{array}$ & $\begin{array}{c}28 \mathrm{~d} \text { abrasion } \\
\text { rate }(\%)\end{array}$ \\
\hline$A_{1}$ & 0.18 & 0.5 & TR & 17 & 10 & 8 & 7.5 & 55.81 & 1.07 \\
\hline$A_{2}$ & 0.18 & 1.0 & QS & 17 & 10 & 8 & 9 & 50.71 & 1.19 \\
\hline$A_{3}$ & 0.18 & 1.5 & SS & 17 & 10 & 8 & 8.5 & 52.00 & 1.00 \\
\hline$A_{4}$ & 0.20 & 0.5 & QS & 17 & 10 & 8 & 9 & 48.72 & 1.20 \\
\hline$A_{5}$ & 0.20 & 1.0 & SS & 17 & 10 & 8 & 11 & 44.33 & 1.39 \\
\hline$A_{6}$ & 0.20 & 1.5 & $\mathrm{TR}$ & 17 & 10 & 8 & 10.5 & 43.95 & 1.40 \\
\hline$A_{7}$ & 0.22 & 0.5 & SS & 17 & 10 & 8 & 10.5 & 44.44 & 1.37 \\
\hline$A_{8}$ & 0.22 & 1.0 & $\mathrm{TR}$ & 17 & 10 & 8 & 11.5 & 43.98 & 1.38 \\
\hline$A_{9}$ & 0.22 & 1.5 & QS & 17 & 10 & 8 & 13 & 40.80 & 1.44 \\
\hline
\end{tabular}

TABLE 9: Test results of $168 \mathrm{~h}$ abrasion resistance strength of rubber UHPC $\mathrm{h} /\left(\mathrm{kg} / \mathrm{m}^{2}\right)$.

\begin{tabular}{|c|c|c|c|c|c|c|c|c|c|c|}
\hline $\begin{array}{l}\text { Group } \\
\text { number }\end{array}$ & $\begin{array}{c}\text { Rubber } \\
\text { content } \\
(\%)\end{array}$ & $\begin{array}{c}\text { Rubber } \\
\text { particle } \\
\text { size } \\
(\text { mesh })\end{array}$ & $\begin{array}{c}\text { Sand } \\
(\%)\end{array}$ & $\begin{array}{c}W / \\
B\end{array}$ & $\begin{array}{c}\text { Silica } \\
\text { powder } \\
(\%)\end{array}$ & $\begin{array}{c}\text { Fly ash } \\
(\%)\end{array}$ & $\begin{array}{c}\text { Steel fiber } \\
(\%)\end{array}$ & $\begin{array}{c}\text { Water reducing } \\
\text { agent }\end{array}$ & $\begin{array}{l}28 \mathrm{~d} \text { abrasion } \\
\text { resistance strength } \\
\mathrm{h} /\left(\mathrm{kg} / \mathrm{m}^{2}\right)\end{array}$ & $\begin{array}{c}28 \mathrm{~d} \\
\text { abrasion rate } \\
(\%)\end{array}$ \\
\hline$B_{1}$ & 10 & 40 & 43 & 0.2 & 15 & 5 & 1 & 10.0 & 60.3 & 1.44 \\
\hline$B_{2}$ & 10 & 16 & 44 & 0.2 & 15 & 5 & 1 & 11.0 & 71.5 & 1.02 \\
\hline$B_{3}$ & 10 & 8 & 45 & 0.2 & 15 & 5 & 1 & 12.5 & 75.6 & 0.96 \\
\hline$B_{4}$ & 12.5 & 40 & 43 & 0.2 & 15 & 5 & 1 & 11.5 & 49.3 & 1.99 \\
\hline$B_{5}$ & 12.5 & 16 & 44 & 0.2 & 15 & 5 & 1 & 12.0 & 52.1 & 1.43 \\
\hline$B_{6}$ & 12.5 & 8 & 45 & 0.2 & 15 & 5 & 1 & 11.0 & 56.0 & 1.32 \\
\hline$B_{7}$ & 15 & 40 & 43 & 0.2 & 15 & 5 & 1 & 13.0 & 32.9 & 2.72 \\
\hline$B_{8}$ & 15 & 16 & 44 & 0.2 & 15 & 5 & 1 & 12.0 & 37.1 & $2.02 \%$ \\
\hline$B_{9}$ & 15 & 8 & 45 & 0.2 & 15 & 5 & 1 & 12.0 & 43.5 & $1.63 \%$ \\
\hline
\end{tabular}

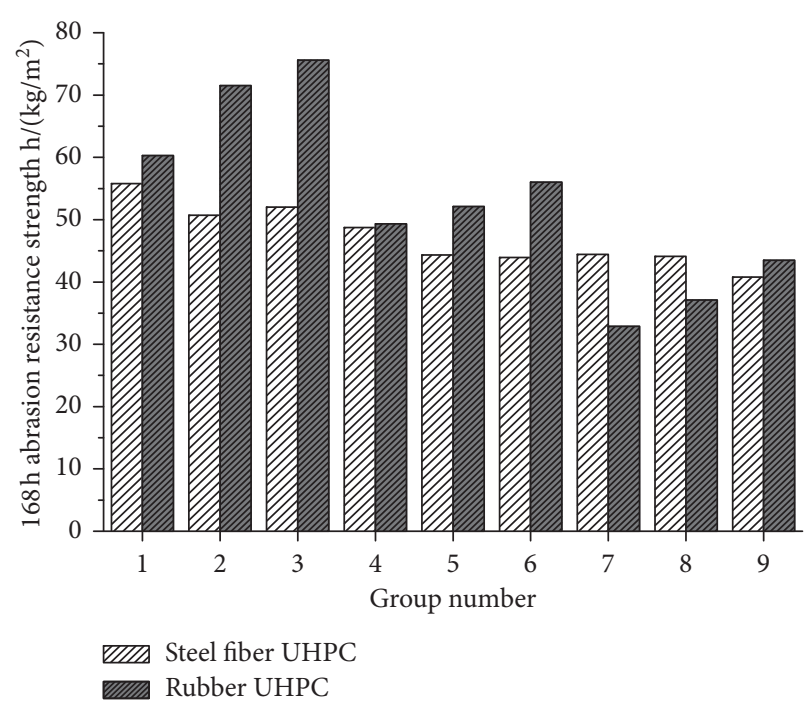

FIGURE 4: $168 \mathrm{~h}$ abrasion resistance strength of rubber UHPC and steel fiber UHPC.

\section{Microstructure Analysis}

In order to better study the inner structure of steel fiber UHPC and rubber UHPC and the morphology of the cement paste-aggregate interface transition zone (ITZ), this experiment was also analyzed by means of scanning electron microscope (SEM). Two groups of steel fiber UHPC test specimens are selected from the orthogonal test, namely, $A_{4}$ test piece (the steel fiber content is $0.5 \%$, the water-binder ratio $(\mathrm{W} / \mathrm{B})$ is 0.2 , and the aggregate type is $\mathrm{QS})$ and $A_{6}$ test piece (the steel fiber content is $1.5 \%$, the water-binder ratio $(\mathrm{W} / \mathrm{B})$ is 0.2 , and the aggregate type is TR); two groups of rubber UHPC test specimens are selected, namely, $\mathrm{B}_{1}$ test piece (the rubber content is $10 \%$, the rubber particle size is 40 mesh, and the steel fiber content is $1 \%$ ) and $B_{3}$ test piece (the rubber content is $10 \%$, the rubber particle size is 8 mesh, and the steel fiber content is $1 \%$ ).

As can be seen from Figure 6 of the SEM, the cement paste-aggregate ITZ between steel fiber UHPC and rubber UHPC (containing 1\% steel fiber) has fewer internal voids and high degree of compaction. However, the bond between rubber as an organic material and cementitious material is weaker than that of steel fiber, resulting in the cement paste-aggregate ITZ of steel fiber UHPC being denser than that of rubber UHPC. With the increase of curing age, slag powder, silica powder, and other ultrafine mineral admixtures can be used for secondary hydration, which can effectively fill the cracks and voids in the interface structure, effectively solve the interface structure defects, and make the ITZ still dense after adding steel fiber and rubber. Therefore, in order to realize the secondary hydration of concrete, the maintenance work is very important for all aspects of performance. It can be seen from Figures 3(b) and 3(c) that the ITZ of 40 mesh rubber particles is denser, because, with a smaller particle size, some of pores in the cement stone are filled, and the 


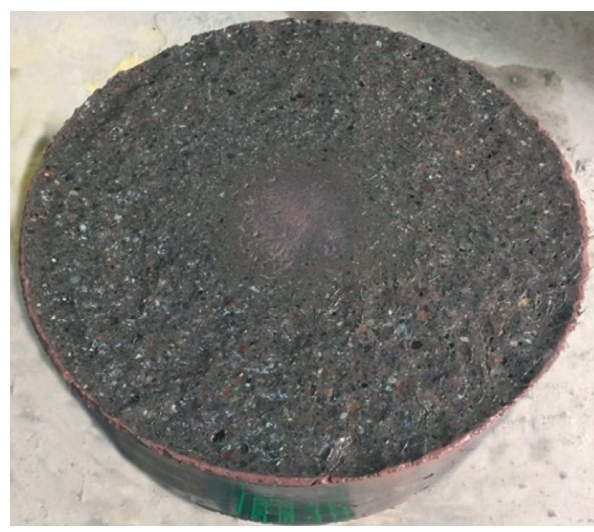

(a)

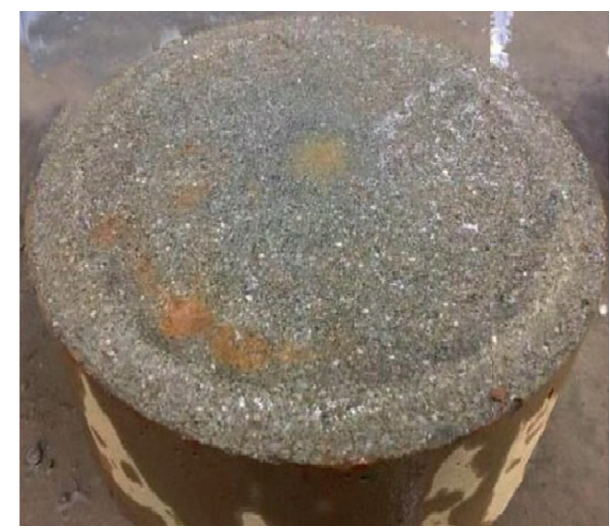

(b)

FIGURE 5: Steel fiber UHPC and rubber UHPC specimens after long impact abrasion for $168 \mathrm{~h}$ : (a) steel fiber UHPC with $1.5 \%$ steel fiber; (b) rubber UHPC with 8 mesh rubber.

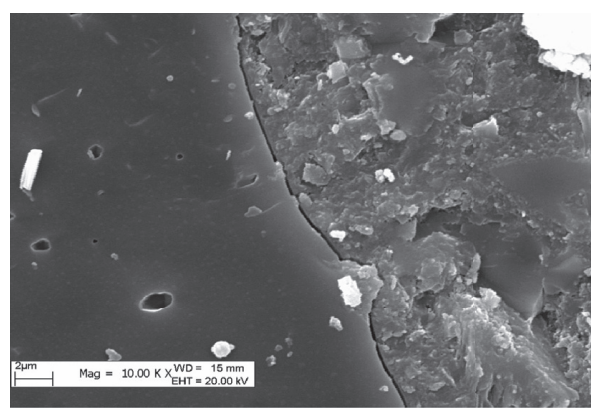

(a)

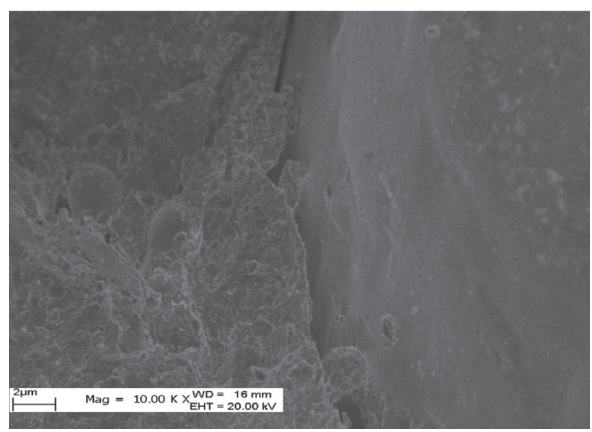

(c)

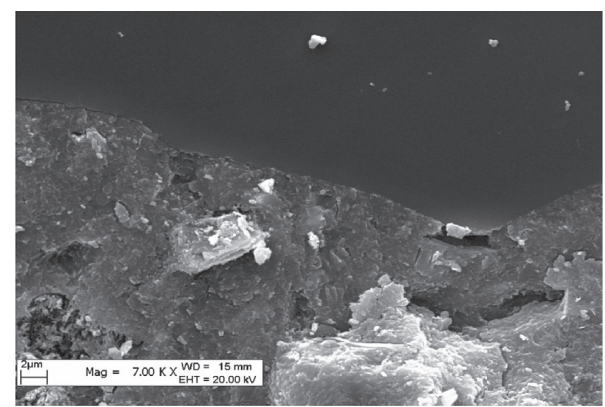

(b)

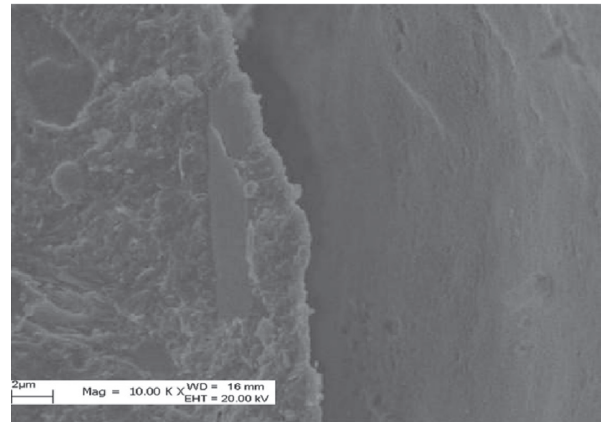

(d)

FIGURE 6: The cement paste-aggregate interface transition zone (ITZ) of steel fiber UHPC and rubber UHPC: (a) steel fiber UHPC with 0.5\% steel fiber; (b) steel fiber UHPC with $1.5 \%$ steel fiber; (c) rubber UHPC with 40 mesh (the length is $0.2-0.4$ mm) rubber; (d) rubber UHPC with 8 mesh (the length is $2-4 \mathrm{~mm}$ ) rubber.

interface structure of cement stone and aggregate is further improved, but this does not mean that the smaller the particle size is, the higher the strength will be.

\section{Conclusions}

(1) The compressive strength of steel fiber UHPC is higher than that of rubber UHPC (containing 1\% steel fiber). When the rubber content is $10 \%$ and $12.5 \%$, the abrasion resistance performance of steel fiber UHPC is significantly lower than that of rubber UHPC (containing 1\% steel fiber); when the rubber content is $15 \%$, the abrasion resistance performance of rubber UHPC (containing 1\% steel fiber) is generally lower than that of steel fiber UHPC, but with the increase of rubber particle size, the abrasion resistance performance of rubber UHPC (containing 1\% steel fiber) is higher than that of steel fiber UHPC.

(2) With the increase of steel fiber content, the increase of UHPC compressive strength is not very obvious. Meanwhile, the abrasion resistance strength 
generally decreases, while the abrasion rate generally increases. The influence of water-binder ratio $(W / B)$ on UHPC is higher than that of steel fiber content.

(3) With the increase of rubber content, the rubber UHPC (containing 1\% steel fiber) compressive strength decreases, abrasion resistance strength decreases, and abrasion rate increases; meanwhile, the proportion of influence different particle sizes on the same content decrease is different. With the increase of the rubber particle size, the abrasion resistance strength increases and the abrasion rate decreases. The order of influence of rubber particle size on UHPC compressive strength is 16 mesh $>40$ mesh $>8$ mesh; the influence factors of rubber UHPC are as follows: rubber content $>$ rubber particle size.

(4) The cement paste-aggregate interface transition zone (ITZ) between steel fiber UHPC and rubber UHPC (containing 1\% steel fiber) has less space and high density; however, the ITZ of steel fiber UHPC is denser than that of rubber UHPC. The compactness of rubber UHPC cement paste-aggregate ITZ mixed with 8 mesh rubber is higher than 40 mesh, but this does not mean that the smaller the particle size is, the higher the strength will be.

\section{Data Availability}

The data used to support the findings of this study are included within the article. All the data were obtained by experimental investigation based on the parameters and methods in this paper.

\section{Conflicts of Interest}

The authors declare that they have no conflicts of interest.

\section{Acknowledgments}

This research was funded by the Xinjiang Natural Science Foundation of China (Grant no. 2019D01A46).

\section{References}

[1] S. Mindess, J. F. Young, and D. Darwin, Concrete, PrenticeHall, Upper Saddle River, NJ, USA, 2nd edition, 2003.

[2] S. K. Rao, P. Sravana, and T. C. Rao, "Abrasion resistance and mechanical properties of roller compacted concrete with GGBS," Construction and Building Materials, vol. 114, pp. 925-933, 2016.

[3] S. Yazıcı and G. İnan, "An investigation on the wear resistance of high strength concretes," Wear, vol. 260, no. 6, pp. 615-618, 2006.

[4] A. M. Neville, Properties of Concrete, Pearson Education Limited, Harlow, UK, 5th edition, 2011.

[5] X. Cai, Z. He, S. Tang, and X. Chen, "Abrasion erosion characteristics of concrete made with moderate heat Portland cement, fly ash and silica fume using sandblasting test," Construction and Building Materials, vol. 127, pp. 804-814, 2016.
[6] F. N. Hao, Study on Evaluation Method of Abrasion Resistance of Hydraulic Concrete, Masters thesis, Northwest A \& F University, Yangling, China, 2012.

[7] T. C. Tu, Research on the Abrasion Resistance of Ultra High Performance Concrete, Dissertations thesis, South China University of Technology, Guangzhou, China, 2018.

[8] J. F. Kang and K. Fan, "Abrasion resistance of rubberized concrete," Journal of Tianjin University Science and Technology, vol. 44, no. 8, pp. 727-731, 2011.

[9] C. V. Silva, J. E. Zorzi, R. C. D. Cruz, and D. C. C. Dal Molin, "Experimental evidence that micro and macrostructural surface properties markedly influence on abrasion resistance of concretes," Wear, vol. 422-423, pp. 191-200, 2019.

[10] R. Siddique and J. M. Khatib, "Abrasion resistance and mechanical properties of high-volume fly ash concrete," Materials and Structures, vol. 43, no. 5, pp. 709-718, 2010.

[11] H. Li, M. H. Zhang, and J. P. Ou, "Abrasion resistance of concrete containing nano-particles for pavement," Wear, vol. 260, no. 11-12, pp. 1262-1266, 2006.

[12] Z. He, X. Chen, H. Yang, and X. Cai, "Hydro-abrasive erosion of concrete incorporated with nano-SiO2, super-fine slag or rubber powder," Wuhan University Journal of Natural Sciences, vol. 18, no. 6, pp. 535-540, 2013.

[13] A. Kılıç, C. D. Atiş, A. Teymen et al., "The influence of aggregate type on the strength and abrasion resistance of high strength concrete," Cement and Concrete Composites, vol. 30, no. 4, pp. 290-296, 2008.

[14] T. Yen, T.-H. Hsu, Y.-W. Liu, and S.-H. Chen, "Influence of class $\mathrm{F}$ fly ash on the abrasion-erosion resistance of highstrength concrete," Construction and Building Materials, vol. 21, no. 2, pp. 458-463, 2007.

[15] H. A. Alaka and L. O. Oyedele, "High volume fly ash concrete: the practical impact of using superabundant dose of high range water reducer," Journal of Building Engineering, vol. 8, pp. 81-90, 2016.

[16] S. Zhao, E. V. Dam, D. Lange et al., "Abrasion resistance and nanoscratch behavior of an ultra-high performance concrete," Journal of Materials in Civil Engineering, vol. 29, no. 2, Article ID 04016212, 2017.

[17] W. G. Wong, P. Fang, and J. K. Pan, "Dynamic properties impact toughness and abrasiveness of polymer-modified pastes by using nondestructive tests," Cement and Concrete Research, vol. 33, no. 9, pp. 1371-1374, 2003.

[18] M. K. Batayneh, I. Marie, and I. Asi, "Promoting the use of crumb rubber concrete in developing countries," Waste Management, vol. 28, no. 11, pp. 2171-2176, 2008.

[19] E. K. Horszczaruk, "Hydro-abrasive erosion of high performance fiber-reinforced concrete," Wear, vol. 267, no. 1-4, pp. 110-115, 2009.

[20] T. C. Cheng, A. Cheng, R. Huang et al., "Abrasion properties of steel fiber reinforced silica fume concrete according to los angeles and water abrasion tests," Materials Science, vol. 20, no. 4, pp. 498-502, 2014.

[21] A. Momber, Hydrodemolition of Concrete Surfaces and Reinforced Concrete, Elsevier, New York, NY, USA, 2005.

[22] Y. C. Guo, F. Liu, G. X. Chen et al., "Experimental investigation on impact resistance of rubberized concrete," Journal of Building Materials, vol. 15, no. 1, pp. 139-144, 2012.

[23] E. Ozbay, M. Lachemi, and U. K. Sevim, "Compressive strength, abrasion resistance and energy absorption capacity of rubberized concretes with and without slag," Materials and Structures, vol. 44, no. 7, pp. 1297-1307, 2011.

[24] B. S. Thomas, S. Kumar, P. Mehra, R. C. Gupta, M. Joseph, and L. J. Csetenyi, "Abrasion resistance of sustainable green 
concrete containing waste tire rubber particles," Construction and Building Materials, vol. 124, pp. 906-909, 2016.

[25] D. Li, J. E. Mills, B. T. Benn et al., "Abrasion and impact resistance investigation of crumbed rubber concrete," in Proceedings of the 23rd Australasian Conference on the Mechanics of Structures and Materials (ACMSM23), Southern Cross University, Lismore, NSW, Australia, December 2014.

[26] Z. K. Khatib and F. M. Bayomy, "Rubberized portland cement concrete," Journal of Materials in Civil Engineering, vol. 11, no. 3, pp. 206-213, 1999.

[27] A. T. Noaman, B. H. Abu Bakar, and H. M. Akil, "Experimental investigation on compression toughness of rubberized steel fibre concrete," Construction and Building Materials, vol. 115, pp. 163-170, 2016.

[28] J. Xie, C. Fang, Z. Lu, Z. Li, and L. Li, "Effects of the addition of silica fume and rubber particles on the compressive behaviour of recycled aggregate concrete with steel fibres," Journal of Cleaner Production, vol. 197, pp. 656-667, 2018.

[29] M. K. H. Ismail, Flexural, Shear, and Mechanical Behaviour of Self-Consolidating-Rubberized Concrete With/without Steel Fibres, Dissertations thesis, Memorial University of Newfoundland, Newfoundland, Canada, 2007.

[30] National Standards of the People's Republic of China, Reactive Powder Concrete, China Standard Press, Beijing, China, GB/ T31387-2015, 2015.

[31] Electric Power Industry Standard of the People's Republic of China, Test Code for Hydraulic Concrete, China Electric Power Press, Beijing, China, DL/T5150-2001, 2002.

[32] Annual Book of ASTM Standards, Standard Test Method for Abrasion Resistance of Concrete (Underwater Method), Annual Book of ASTM Standards, ASTM International, West Conshohocken, USA, ASTM C1138-97, 2002.

[33] Water Conservancy Industry Standard of the People's Republic of China, Test Code for Hydraulic Concrete, China Water Conservancy and Hydropower Press, Beijing, China, SL352-2006, 2006. 